\title{
Life's continuation: repro-tech, biogenetic affinity, and racial capitalism
}

\author{
Nadine Ehlers ${ }^{1}$
}

Accepted: 30 August 2021 / Published online: 27 October 2021

(C) The Author(s) 2021

\begin{abstract}
This paper examines the affinity ties of biological and familial whiteness in ART as evident in the 2014 Illinois Northern District Court case of Cramblett $v$. Midwest Sperm Bank-where a white mother filed a wrongful birth suit and sought legal compensation for the loss of perceived genetic similarity and giving birth to a 'black' child via donor insemination. Applying critical legal and critical race studies to the case and engaging its surrounding media, the paper considers what Cramblett can tell us about loss - as it is related to notions of value and property within an overarching system of racial capitalism. This paper considers how race, value, and property inter-articulated in Cramblett through notions of biogenetic relations and familial whiteness within the organization of family; how these ideas travel through to investments in life - and its continuation-as a form of racial property (for some); and what this case can tell us about broader operations of structural racism and the role of biomedicine (and law) within these operations. Ultimately, the paper shows that biogenetic affinity in ARTs condition life's continuation in ways that resecure the disparities of racial capitalism.
\end{abstract}

Keywords Race $\cdot$ Value $\cdot$ Property $\cdot$ Racial capitalism $\cdot$ ARTs

Regardless of how technology has freed us ... [w]e still have the messy nucleus of procreation's racial order to contend with.

- Holland (2012)

Racist structures not only produce, but reproduce whiteness, by resuscitating the myth of white innocence that inheres in the racial status quo. Racist systems are thereby reproductive systems.

-Benjamin (2018)

Nadine Ehlers

nadine.ehlers@sydney.edu.au

1 University of Sydney, Department of Sociology and Social Policy, Sydney, Australia 
In late 2014, a case involving an IVF 'mix-up' was brought before the Illinois District Court. Commenting on the case, The New Yorker noted that the white plaintiff, Jennifer Cramblett, "“did not know African Americans until her college days at the University of Akron.' Then, in 2012, she gave birth to one” (McKnight 2014). Cramblett filed both 'wrongful birth' and 'breach of warranty' lawsuits in September of 2014. She alleged that the Chicago-based Midwest Sperm Bank had supplied the wrong sperm - from a black rather than a white donor-and was suing for in excess of $\$ 50,000$ damages on each count. The complaint stated that, due to the error, Jennifer Cramblett had "suffered personal injuries, medical expenses, pain, suffering, emotional distress, and other economic and non-economic losses, and will do so in the future" (Cramblett II 31). ${ }^{1}$

If the complaint in Cramblett v. Midwest Sperm Bank centered on perceived loss and operated as an effort to seek compensation against such loss, it becomes essential to ask: what exactly constitute these losses? Applying critical legal and critical race studies to the case and engaging its surrounding media, this paper considers what Cramblett can tell us about loss-where loss denotes the fact or process of something being taken away or the deprivation of something of value. While others have also examined this case in terms of loss (e.g., Lenon and Peers 2017; Rich 2020), I am particularly interested in how loss is related to property (an attribute, belonging, or possession-material or immaterial) within an overarching system of racial capitalism. In invoking racial capitalism, I call on Cedric Robinson's understanding that "the development, organization, and expansion of capitalist society pursued essentially racial directions," and that relations under capitalism require and intensify difference and differentiation - particularly the unequal differentiation of human value-in large part along racial lines (1983, p. 2). ${ }^{2}$ My questions here are how are race, value, and property inter-articulated in Cramblett through notions of biogenetic relations and familial whiteness within the organization of family; how do these ideas travel through to investments in life-and its continuation-as a form of racial property (for some); and what can this case tell us about broader workings of structural racism and the role of biomedicine (and law) within these operations?

In exploring these ideas, I consider how this uniquely American but indeed exceptional story resonates with wider racial logics in the USA, which have established the black/white racial divide or color line as the most salient and enduring in what Hortense Spillers has called the "American grammar" of race (1987, p. 68). Broader research on reproduction and its inter-articulations with race, value, and nation/citizenship has addressed transracial adoption (Eng 2010) and reproductive

\footnotetext{
1 My emphasis. Cramblett v. Midwest Sperm Bank, LLC. 'Complaint for Wrongful Birth and Breach of Warranty.' 29 Sept 2014. Circuit Court of Cooks County, Illinois. Also see the motion to dismiss, Cramblett v. Midwest Sperm Bank, LLC. No. 15 L 000282. Note that Cramblett filed her original complaint in Cook County Circuit Court, and the case was transferred to DuPage County on March 24, 2015. The complaint alleged both wrongful birth and breach of warranty pursuant to the Blood and Organ Transaction Liability Act (745 ILCS 40/3 (West 2014)).

${ }^{2}$ I say partly, because capitalism also clearly emerged along gendered lines.
} 
labor related to transnational surrogacy or oocyte procurement (e.g., Cooper and Waldby 2014; Deomampo 2016; Harrison 2016; Peterson and Myong 2015; Vora 2015: Weinbaum 2019; Waldby 2019). Here I scale down to consider the racial politics of ART using sperm donors, focusing on the kinds of work sperm is called on to do and the losses it can inaugurate. Two key points structure my understanding of the dynamics of loss evident in the Cramblett case and the interrelations of biomedicine and racial capitalism. First, I draw on Michel Foucault's understanding of technology, to position race as a technology or instrument that produces certain outcomes (qua racial classifications) (Ehlers 2012, pp. 23-28). In the context of this paper, the technology of race — articulated through notions of biogenetic affinity-is mobilized beyond the lab to make family. Second, this making of family, enabled through ARTs, advances in ways that augment systems of racialized inequity, such that the reproduction of species being cannot be divorced from the reproduction of relations of capital (financial or otherwise).

\section{Organizing racial 'families'}

Assisted reproductive technologies (ART) can be used to challenge the notion that kinship is based on biology-for instance, when users call on a donor to facilitate familial belonging. ${ }^{3}$ They can also be used, however, to reaffirm the idea that biogenetic relation is the basis for kinship: by choosing a donor who resembles the legal parent(s), users reassert the importance of supposed biogenetic connections-a belief that "has a long history linked to inheritance, lineage, and genealogy" (Griffiths 2016, p. 199). This production of a form of relatedness is what Laura Mamo calls an 'affinity-tie.' She describes this production as "a kinship device co-constructed between ... [clients] imagining shared social and cultural characteristics and sperm banks' investment of the biomaterial, sperm, with an ability to create relatedness" (2005, pp. 237-238). In donor IVF specifically, relatedness-the affinity-tiecan be achieved by choosing sperm that will have an affinity to the ART user both in a socio-cultural and loose biogenetic sense-predicated on notions of similarity.

Importantly, race is often used as a proxy for affinity in ART: affinity is racialized, with genes often positioned as that which transfers racial identity. The significance of the idea of inheritability via genes as intimately tied to identity is evident when IVF donors are chosen based on racial categorization in order to facilitate biogenetic relation (or best approximation). Such efforts represent a paradox given that genetics has resolutely shown that there is no genetic basis for race and that commonly defined racial groups are genetically heterogeneous and thus lack clear-cut boundaries (Nelson 2016; Roberts 2011; Fullwiley 2007; Kahn et al 2018). Regardless of this reality, both the idea of race and biomedicine can be deployed beyond the lab

\footnotetext{
3 Assisted reproductive technologies encompass almost all infertility services, including artificial insemination, egg donation, egg and embryo freezing, surrogacy, in-vitro fertilization (IVF), and pre-implantation genetic diagnosis. Here I use the term generically to refer to technologized assistance with reproduction, though I specifically focus on IVF, the technology used by Jennifer Cramblett.
} 
for intimate use: to create these affinity ties of supposed racial biogenetic relation. In doing so, repro-tech is never simply biomedical: it is structured through and fortifies racial capitalism. As Nikhil Singh has noted, in the workings of racial capitalism, " $[\mathrm{t}$ ]he production of race as a method for aggregating and devaluing [or privileging] an entire group has depended on assessing the value of Black [and white] social and biological reproduction in terms of capital accumulation and its social reproduction" (2017, pp. 57-58). While I expand on these ideas in more detail below, it is worth noting at this point that we see the fortification of racial capitalism via ARTs in two key senses. First, reproductive technologies can be used to resecure epistemologies and ontologies of kinship and inheritance, where race is imagined as an inheritable (genetic) property. As I go on to explain, the notion of racial identity as property is tied particularly to whiteness in the US. Here, reproduction, understood as the maintenance of species-being, is inseparable from racialized power/knowledge relations that privilege white racial identity — both personal and collective-above others. Second, repro-tech is inextricable from political economy and broader property relations that rely on disparity: it is conditioned by market forces and logics, and it enables the reproduction of relations of capital accumulation. Together, these factors direct racial futures.

The notion of creating affinity ties based on race is articulated in an interview with CNN, where Jennifer Cramblett claimed she and her partner, Amanda, chose a "blond-haired, blue-eyed individual" as their sperm donor so that their potential child would closely resemble her partner (Cuevas 2014). Reiterated in the legal complaint, "[t]heir desire was to find a donor with genetic traits similar to both of them." Their plan was that Jennifer would carry the first child and, "at a subsequent time, Amanda would become inseminated with sperm from the same donor so that their children would be blood-related" (Cramblett 9I 9). While not explicitly stated, Cramblett and her partner were seeking to reproduce a racially homogenous family through the commercial object of 'white sperm' - the biomaterial they presumed they had bought and now possessed as property.

Their intention shows that the desire for familial race concordance is not an idea relegated to the past, nor is it accidental. Indeed, a 2017 Pew Research study found that only $10 \%$ of women had married someone of a different race or ethnicity in 2015. These figures might seem higher than expected, and they do represent a significant increase in interracial relationships over the last decade. The study noted, however, that while whites in general have experienced a rapid increase in intermarriage, "with rates [of newlyweds] rising from 4 to $11 \%$," they nonetheless "remain the least likely of all major racial or ethnic groups to marry someone of a different race or ethnicity" (Livingston and Brown 2017). This fact becomes important when we consider that racially endogamous marriages facilitate the socio-political reproduction of racial categories through the literal bodily reproduction of children within such marriages-creating the possibility for familial race concordance: that is, where members of the family all share the same socially recognized racial categorization. Despite these findings indicating the rise of interracial coupling in broader US society, monoracial family formation remains privileged, particularly within white communities, as the aforementioned Pew Research study suggests, and this privileging is reflected within ARTs (even if it is perhaps not explicitly articulated). 
The privileging of race-concordant families can be seen in a various aspects of ART clinical practice. For instance, one of the main ways that donor registers are delineated and organized is by race-a reality that makes it almost impossible for users to not know the race of a chosen donor. Moreover, this differentiation and sorting of donors by race actually steers potential parents toward race concordance, as Dov Fox (2014) has noted, priming individuals to think in racial terms and foregrounding race as a key consideration in thinking about family formation. Camisha Russell goes as far as to say that race is actually policed in ART, from ascribing donor gametes a 'race,' to tracking donor gametes in terms of their 'race,' and through to the "selection... in terms of 'race' of who can or should use which donor gametes" (2018, p. 105). ${ }^{4}$ Together these factors discourage the transgression of family monoraciality and augment the notion that "kinship has a color" (Lenhardt 2017, p. 2075).

This color of kinship is evident in Cramblett's desire to have a child who was "genetically similar" to both herself and her partner. We can understand this to mean that Cramblett and her partner desired that the child would look like them: clearly, this would mean that the potential child would racially resemble the couple at the embodied visual register. The affinity-tie being created, then, was one of familial whiteness-rendered biological due to the supposed association with genetics. This "white genetic tie," as Dorothy Roberts has stated, "is an extremely valuable attribute entitling... a privileged status" (1997, p. 269). However, the birth of a child socially defined as black meant this desired tie, and associated genetic parentage, was lost. This loss is only possible due to the fact that whiteness can only exist in 'pure' or 'undiluted' form in the US, due to the historical injury of the notion of hypodescent (or the one-drop rule, which asserted that any degree of black ancestry was sufficient to classify an individual as black). As a range of critical legal theorists and historians of race in the US have shown, the entire history of anti-miscegenation and racial classification laws attest to this insistence on supposed white purity (Saks 2000; Haney López 1996; Harris 1993; Kennedy 2000). Moreover, histories of racial reproduction highlight the intricate ways interracial intimacy and the possible production of interracial children was policed in US society to keep whiteness white (Zack 1993; Stokes 2001; Holland 2012; Ehlers 2012). Most recently, Brigitte Fielder has noted that whiteness depends on exclusions-defining white people against those excluded/demarcated as not white-and on the ability of whiteness to reproduce itself. In this context, "[t]he importance of racial reproduction becomes visible when white reproduction fails" (2020, p. 14). While laws prohibiting interracial mixing might be ascribed to another era, the idea continues informally-with individuals with any black ancestry usually socially demarcated as black.

The loss of the familial whiteness in the Cramblett case highlights that what Charis Thompson has called the "ontological choreography" of matching created child with the right or correct parent via ARTs can be disturbed (2005). In this case, the intended match was race congruence-where whiteness reproduces itself-a point stressed in the complaint with the explanation that, after finding out about the

\footnotetext{
4 Also see Quiroga (2007, p. 148), who argues that doctors and clinics enable forms of reproduction that "create biogenetic ties while seemingly ensuring race purity."
} 
mistake, "Jennifer was crying, confused, and upset." Echoing the notion of careful choreography (and its failure), the complaint declared: "All of the thought, care and planning that she [Jennifer] and Amanda had undertaken to control their baby's parentage had been rendered meaningless." And, "[i]n an instant ... excitement and anticipation ... was replaced with anger, disappointment and fear" (Cramblett II 17). Marking the central role of family formation/organization under racial capitalism, where races are defined as distinct and hierarchically arranged, Cramblett, by her own account, had suffered the loss of a range of 'things' of value: affinity, visual racial resemblance with the child, and familial whiteness. Ultimately, she did not get what she paid for, or, in Camille Gear Rich's words, what she "contracted for" (2020, p. 37). ${ }^{5}$

Importantly, this fact - that she did not get what she paid for-and the 'mix-up' overall-was framed as a wrongful birth within the legal complaint, a claim that carries internal to it the supposition that the child should not have been born. Ordinarily, wrongful birth is a malpractice claim brought against medical personnel who fail to notify parents of congenital diseases, disabilities, or birth defects so they can avoid or terminate the pregnancy. It is a claim of a civil 'wrong' on the basis of the denial of the right to avoid the birth of a child with a (said) defect. The child in this case had no medical condition. What was wrong instead was the child's race. And this wrong has two key effects. First, this wrong-that is, the different race of the child-results in a lack of kinship or supposed natural connection between parent/s and child, as I have already noted. That the child's race can be a wrong is evident in the complaint when Cramblett recalls that the receptionist at Midwest asked if she had requested an African American donor, to which Cramblett replied: "No, why would I request that? My partner and I are Caucasian" (Cramblett II 15). We can infer from this that having a mixed-race child was out of the question in Cramblett's attempt to create an affinity-tie with her potential child: it was at odds with her reproductive intent. And, this loss of the affinity-tie of whiteness results in the loss of (continued) white lineage (a point I return to later). Second, this specific claim of a civil wrong positions blackness as synonymous with disability. ${ }^{6}$ Wrongful birth, as noted above, implies a biological defect or disability. However, as there was no such defect or disability associated with the child, Payton, her blackness ostensibly stands in for the supposed disability on which the wrongful birth claim relies. Put another way, if there is no disability, but what is supposedly wrong with the child is that she is black, then it is the child's blackness that is at the root of the wrongful birth claim-a claim predicated on the notion of undisclosed disability; the disability according to this case is the child's blackness. Moreover, because claims of wrongful birth are based on the tort theory of negligence, plaintiffs must demonstrate that the disability of the child has caused injury and harm. In relation to this case, then, blackness is framed as a disability that causes injury. The question is, is this injury

\footnotetext{
5 Also see Houghton-Larsen (2019), who looks at payment, and the failure of delivery on payment in relation to ART, across a range of legal cases.

${ }^{6}$ I do not focus on the specifics of disability in relation to the case here. See Valentine (2020), Kearl (2018), Paul-Emile (2018), Brown (2018), Lenon and Peers (2017).
} 
to the mother, to the child, or to both? While I go on to further explore these ideas in the next section, it is important to note at this point that the wrongful birth claim leveled against the blackness of a child (cast as a form of disability) can, on the one hand, be viewed as a public mourning for whiteness (Kearl 2018, p. 306). However, such mourning - the articulation of loss-can only occur due to differential valuations of life intrinsic to racial capitalism. On the other hand, we could view the case overall as an instantiation of structural violence and racism-where a white woman demands redress for having a black child, a possibility that again rests on disparate scales of value and entitlement associated with (different forms of) racial life.

The tortuous arc of US history has established a clear negative valuation of blackness in relation to and against white life-where whiteness has denoted positive presence and blackness has been positioned as negative absence (of social recognition, volition, subjecthood, and value) (Hartman 1997, p. 21). ${ }^{7}$ These ideas inevitably influence ART use and practice in the sense that, beyond coupling biogenetic affinity with race- thereby positioning race as heritable and thus having biological status-donor-based ART also affirms social beliefs of a genetic foundation of stratified human value. By this I mean that, as a market-based reproductive economy, ART (especially that involving donors) traffics in idealized human traits, traits that are inevitably racialized and hierarchized. ${ }^{8}$ This is a market that commodifies both human life (putting a price on the creation of life) and specific human traits. As Daisy Deomampo has argued, "race materializes and becomes commodified in the context of ART," functioning as a marketized resource (2019, p. 2019). Donor registries, as already noted, are divided by race. Race is one of the primary way donors are identified to potential users and, until recently, one of the largest sperm donation services in the world, California Cryobank, stored and shipped semen in color-coded vials (black, white, yellow, and red [for 'unique' or mixed-raced donors]) (Fox 2009, pp. 1853-1854; Fox 2021). More than merely reproducing racial classification, however, donor services reinforce the negative relation of blackness: they often push 'elite sperm' from men who have attended four-year colleges, the idea being that the highest quality sperm comes from these men, while lower income men (often minorities) are at the bottom. The donor catalog thus operates as a proxy for racial pedigree (Quiroga 2007, p. 150) and promotes race-based hierarchies, reflecting broader workings of race and associated value within racial capitalism.

In this privatized industry white tissue carries greater value, both symbolically and in literal market terms (Almeling 2007; Deomampo 2019; Moll 2019; Martin 2017), and agencies recruit potential donors within the context of this reality (note that the term 'donor' is a misnomer, given that this is a renumerated service). As Fox (2014) claims, donor services could be seen as simply responding to consumer preferences for phenotypical or supposed genotypical sameness. Importantly,

\footnotetext{
7 Such ideas can be placed within a theorization of anti-blackness, understood not as racist acts or violence against the black body, but as "the violence that positions sentient beings outside the realm of the Human" (Bliss 2015, p. 89). On anti-blackness in relation to the Cramblett case, see Shange (2014).

8 See Daniels and Heidt-Forsythe (2012), for instance, who argue that this process can be characterized as a form of "gendered eugenics." Below I problematize the idea that this is a new form of eugenics.
} 
however, most fertility service users are white. This reality is reflected in a 2013 National Survey of Family Growth report by the Centers for Disease Control and Prevention ("CDC"), which found that white women are almost twice as likely to seek medical help to get pregnant: $15 \%$ of white women sought medical help for infertility compared to $7.6 \%$ of Hispanic women and $8 \%$ of black women (Chandra et al. 2013). Given this context, ART services' privileging of white donors augments white racial value - an idea that is then resecured through user selectivity. Moreover, such services accentuate race in ways that invite individuals to exclude all donors of a particular race (Fox 2009).

In the Cramblett case, whiteness is clearly laden with positive value. As I have suggested to this point, the complaint ostensibly rests on the notion that a white sperm donor would have facilitated biogenetic affinity and ties of whiteness, kinship, and necessarily white familial inheritance. The normative force of a wrongful birth lawsuit highlights that, for Jennifer Cramblett, each of these possibilities have been lost because a black rather than a white donor was used: this child should not have been born because she is not a white child. Cramblett didn't get what she paid for, and what she was given (a black child) is socially devalued. The case, then, can be viewed as a demand for rectification: in the words of Camille Gear Rich, the suit rested on the claim that (the wrong) "racial products" had been exchanged and Cramblett was demanding her "just due" (2020, p. 57). Yet in order to raise a wrongful birth claim, plaintiffs must also clearly articulate damages and expenses generated by the disabling condition, which in this case is the 'condition of blackness' (the supposed origin of damage or injury for which compensation is sought). What then are these damages or expenses incurred due to the loss of (white) biogenetic affinity? Put another way, what are the costs exacted by the loss of biogenetic affinity, or, more precisely, what are the costs of blackness?

\section{Investments in life as property}

The first cost of the child's blackness is that it brings about Cramblett's loss of white property in herself - and the property rights of whiteness. Here I refer to critical race scholar Cheryl Harris' claim that whiteness has and continues to be valorized "as treasured property in a society structured on racial caste" (1993, p. 1713). Whiteness was historically constructed as property in the US-both in terms of being a possession and a right—in "the extrinsic, public, and legal realms" (1993, p. 1725). As a right, Harris argues that whiteness has included the rights of use and enjoyment; white racial classification can be used as a deployable resource at the social, political, and institutional level to maintain control and privilege. It is also a type of status property, in that people have a reputational interest in being white. And whiteness additionally involves the right to exclude - to demarcate who can and cannot be considered white and thus access advantages attached to white identity status. Clearly whiteness no longer holds literal legal rights and the case avoids property law. However, whiteness is framed as a property right in the complaint in that Cramblett describes the personal losses that she experiences only now due to the birth of the child, Payton. Previous structural 'rights'/privileges she had enjoyed are no longer 
available, due to her new-found proximity to blackness. Thus, while it is important to note that the case does recognize the social-political factors that create and sustain patterns of racism, it is Cramblett - the white mother-who is positioned in the case as requiring compensation: she is the site of redress. This framing suggests that it is the child's birth that initiates the incursion on her previous reality: that is, her white 'rights.'

Because of the child, Cramblett says that she now has to travel into non-white spaces. For example, the very act of having the child's hair done means she needs to go to hairdressers in black neighborhoods. This is a forced mobility, it unsettles her race-based comfort, and means she is met with new proximities where, as she says in the complaint, she "is not overtly welcome" (Cramblett II 24). She says she has "limited cultural competency relative to African Americans," a statement which implies the child's race will bring discomfort (Cramblett II 23). And, she will also be exposed to the racism of both her wider community and immediate family. Cramblett states that "she was raised around stereotypical attitudes about people other than those in her all-white environment" and that "[f]amily members, one uncle in particular, speaks openly and derisively about persons of color" (Cramblett II 22). She can no longer live comfortably in this racist environment. The child then is the harm that evacuates Cramblett's ability to freely 'use and enjoy' whiteness. As stated in The New Yorker: "[b]y arguing that a child with darker skin and hair that is different from hers is an impediment to her chosen lifestyle, Cramblett tacitly condones the hierarchy in this country that determines the relative worth of one life over another" (McKnight 2014).

This read necessarily needs to take into account the non-heteronormative relationship of Cramblett and her partner Amanda, as the loss of white privilege has further implications in this context. Looking at non-heterosexual ART use, Suzanne Lenon and Danielle Peers (2017, p. 6) have argued that white monoracial gay and lesbian couples tend to select gametes that match their racial group, and avoid 'queering' the family more, thus exercising a form of homonormative privilege, where reproductive intent follows a model consistent with heterosexual norms of white monoracial family formation. Stine Willum Adrian (2020, p. 547) has suggested that such choices function as a way to "reinscribe the child into society" — as white-in a social context where "lack of family homogeneity is used to [further] deny the legitimacy of same-sex families" (Ryan and Mora 2017, p. 586). Here it becomes important to consider how there may be more at stake in the loss of white privilege-through familial proximity to a child demarcated as black-for those white individuals less privileged in the schemata of race.

The second cost of the child's blackness is Cramblett's loss of white property in the intended child. This could be viewed as a loss of investment in genetic capital, in an ART context where biogenetic affinity is cast as racial despite the non-genetic basis of race. Here I mean that Cramblett's desire for biogenetic affinity can be interpreted as what George Lipsitz (1998) has called a "possessive investment in whiteness"- that is, the effort to maintain the structured advantages linked to white racial identity, both for herself and her future child through the continuation of white lineage. Viewed through this lens, it can be tempting to see race-matching in IVF (by whites) as a form of neo-eugenics, a kind of 'better breeding' to maintain systems 
of individual and collective white structural advantage. Cramblett's desired racematching and the resulting error and legal case are no exception, with the Guardian, for instance, insisting that the scenario "smacks of eugenics" (Bindel 2014). But, as Nikolas Rose has been quick to point out, eugenics presupposes state-sponsored coercion and a formulated racially stratified agenda (2007, pp. 62-63). This is no longer at work in late liberalism. Instead, what ART users are faced with now is a neoliberal choice to maximize human capital by making a rational decision on the supposed 'genetic capital' of offspring. In Rose's words, the "regulation of conduct becomes a matter of each individual's desire to govern their own conduct freely in the service of the maximization of a version of their happiness and fulfillment that they take to be their own" (Rose 1996, p. 58). This choice, however, cannot be divorced from broader forces and institutions that inform and manage our conduct. In the context of investment in a potential child's genetic capital, for example, personal choice is inextricable from socio-historical realities of racial hierarchyas they are embedded within social, economic, political and environmental structures-even if these realities recede in conscious decision-making. The advantages of continuing white lineage — investing in supposed genetic capital-are clearly both immaterial and material. This investment is not simply identity based, precisely because the social capital of whiteness is inextricable from relations of capital accumulation which rely and thrive on systems of severe inequality. In Gilmore's pithy summary, "capitalism requires inequality and racism enshrines it" (2015). ${ }^{9}$

The birth of a child socially defined as black means that, rather than accruing what W.E.B. Du Bois (1999 [1920]) referred to as 'dividends' of whiteness (both psychic and material), Cramblett will be met with the costs of blackness. As noted in coverage of the case in Ebony magazine, the associated lifelong costs of raising a black child are linked to financial, emotional, and social burden. Specifically, "[w] hite racism costs money, even for white people" raising black children. "It effects where you live, the school children will attend, and how you socialize" (Johnson 2014). Cramblett might have been claiming compensation for the past mistake by the sperm bank, but she was also making claims for future losses (economic and noneconomic). Accordingly, following the Ebony coverage, the case rests on attempting to "determine future reparations, basically the cost above and beyond whiteness in order to function as black in America due to racism" (Johnson 2014). The demand for reparation works in opposite temporal directions then, to claim compensation for both past and future injury, and these reparations are to be paid to a white woman who will be 'burdened' with protecting this black life.

Following the birth of Payton, Cramblett must now assume many costs, including the expense of moving from her "racially intolerant," "all-white environment" to a more racially mixed area (Cramblett II 22). Indeed, according to the complaint, "all of Jennifer's therapists and experts agree that for her psychological and parental well-being, she must relocate to a racially diverse community with good schools" (Cramblett II 27). Though she had initially "moved to [white] Uniontown

\footnotetext{
9 Also see Taylor (2016, p. 206), who argues that capitalism has "used racism to justify plunder, conquest, and slavery," to simply "divide and rule."
} 
from racially diverse Akron because the schools were better and to be closer to family" (Cramblett II 26), Cramblett must now assume the financial burden of finding a new home for her family and a new school for the child. Not only does the birth of Payton depreciate Cramblett's property in whiteness, then, it also opens the way to financial costs and loss of physical property-e.g., equity in her house and future accumulated wealth from that property that could then be passed down as inheritance, enabling the reproduction of compounding relations of capital accumulation. Had Cramblett delivered a white child, this would have enabled her to stay in Uniontown which, according to recent census figures is $97 \%$ white and $0 \%$ black, has a 90.6\% matriculation rate for high school graduation or higher, has a poverty rate of only $7.2 \%$ (as opposed to Akron, for instance, which has a $23.33 \%$ poverty rate and $30 \%$ black population), and where the medium house value is at least $25 \%$ higher than average Ohio metro areas. ${ }^{10}$ Clearly, if Cramblett had a white child, the family as a whole could have benefited from this environment and the possibilities for material accumulation it offers. What this case shows in this instance, then, is how whiteness and racism operate structurally in the US to organize society and adjudicate life and life chances.

The cost of blackness is obviously not just to the white mother, however. As a stigmatized status in the US, blackness was designed to be disabling (Paul-Emile 2018, p. 2815) within an overarching system where, as Cheryl Harris has recently stated, "whiteness mitigates risk through racial/spatial structures that sort probabilities and distribute access and opportunity" - as we see with the demographics of Uniontown above (2020, p. 6). Within this context, all too familiar costs are imposed on black people including; increased likelihood, relative to whites, of living in poverty, experiencing discrimination in housing, attending failing schools, receiving inferior medical care, etc. These costs are at the heart of racial capitalism, which is based on "antinomies of accumulation [that] require loss [and] disposability ... [alongside] the unequal differentiation of human value" (Melamed 2015, p. 77).

As Jennifer Cramblett makes clear in the complaint, Payton will face harm: she will be "stigmatized" because her "differences are irrepressible" (Cramblett II 25). The reality of the structural violence of racism is followed through in media commentary on the case, when Matthew McKnight from The New Yorker notes:

The tragic irony here is that Cramblett is right to fear for her daughter's future. It is likely that her daughter will not enjoy the privileges of first-class citizenship: she probably won't be regarded and treated according to her worth, and she probably won't be protected from the suspicions, fears, and judgments with which people will react to her skin color (2014).

Marking the precarity of black life, what Frantz Fanon (2000 [1952]) called the "fact of blackness" carries a price then. And in a very dystopian read, we could interpret Cramblett as seeking compensation not just for the costs incurred by this black life but also for the projected (and thwarted) loss of future return on a white child's

${ }^{10}$ For Uniontown figures see: https://censusreporter.org/profiles/16000US3978736-uniontown-oh/. For Akron figures see: https://worldpopulationreview.com/us-cities/akron-oh-population. 
body-with all the future economic value and financial yield that could be associated with that body. ${ }^{11}$ In the words of Saidiya Hartman (2014), Payton takes "the space of a more qualified, more desired white candidate, erupting into the world as damaged goods." In doing so, she evacuates the potential investment return linked to white racial value, resulting in Cramblett forfeiting the reproductive relations of (white racial) capital accumulation.

Despite the myriad losses articulated through the complaint, in simply mounting this case Cramblett demonstrates that, as a white woman, she gets a choice around reproduction as it is linked to supposed rights. She is in the position and has the capacity to claim certain privileges related to reproduction and to seek to recoup the various costs associated with the birth of her child. This capacity must necessarily be read against both the realities of black women's lack of choice around the contours of life's continuation in the US, as evidenced through high female mortality rates in pregnancy and birth, and the enduring asymmetry of racialized biological citizenship (Pollock 2015; Krupar and Ehlers 2017; Davis 2020). Indeed, the case highlights that white identity is linked to a command of a propertied self and is viewed, and validated, as a self-determining and rights-based subjectivity, marked by notions of sovereignty.

\section{Conclusion}

As I have explored throughout this analysis, the concept of biogenetic affinity in sperm donor-based ART structures and limits kinship-precisely because of the enduring idea that kinship has a color. The technology of race, then, is mobilized both within and beyond the lab in family-making - where the reproduction of species-being using ARTs operates within a social reality where species-being is 'cut' by the caesura of race (Foucault 2003). Linked to this, the concept of biogenetic affinity can augment the stratified valuation of life along racial lines-where the majority of those accessing ART donor services are white and seek to create familial whiteness as lineage, indeed, as a form of property. The concept of maintaining 'white' biogenetic affinity - the reproduction of a particular form of species-beingcannot, however, be divorced from the reproduction of relations of capital accumulation, as evidenced in Cramblett v. Midwest Sperm Bank. As Kathryn Yussof (2019, p. 66) has noted, "[t]he inheritance of ideal subjecthood ... is tied to material accumulation vis-à-vis the white ... family." Race, property, and value are inextricably linked in the overarching operations of racial capitalism.

Ultimately, biomedicine plays a key role in these operations. Biomedicine facilitates family formation via technological means, but it specifically enables

\footnotetext{
11 Also see Foucault (2008, p. 244), who argues that investment in a child's human capital "will produce an income. What will this income be? It will be the child's salary when he or she becomes and adult." While Foucault it referring to investment as 'time spent' and 'quality of care' provided to the child, the argument can aptly be applied to race. Investing in creating a white child will lead to a certain kind of 'profit.'
} 
individuals to pursue family formation alone lines of race: ART donor services are organized by (and reproduce) racial hierarchies and associated value, and within ARTs race is positioned as proxy for affinity. As such, biomedicine is complicit in and can be used/deployed to affirm structural racism. Likewise, law is implicated in maintaining racial logics and ontologies of relative racial value. Cramblett positions law as arbiter in the question of blackness as wrongful birth—seeking legal redress for the losses incurred by the supposed 'injury' of this birth. Ultimately, however, Cramblett was unsuccessful. DuPage County Circuit Court Judge Ronald Sutter dismissed the complaint in 2015, writing, "under Illinois law [Cramblett] is precluded from recovery costs associated with raising a normal, healthy child" (Gutowski 2015). Sutter insisted that legal standards do not recognize claims for healthy babies in wrongful birth claims. Importantly, however, in making this statement, the court failed to address race at all. By this I mean that no mention was made of race in the dismissal and, as such, the issue that was at the very heart of the wrongful birth claim was silenced and rendered invisible. Indeed, the court neglected the opportunity to address/redress enduring racism and to contest the very conditions of possibility that gave rise to this case in the first place. As such, law can be seen to operate here as structural armature maintaining the racial status quo.

The particularities of this case and the finding might be just one specific story, but they are telling, in that they speak to something much larger in the structuring of US society. Cramblett v. Midwest Sperm Bank reflects, as Sharon Holland (2012, p. 60) has argued, that "racist practice is still haunted by reproduction's persuasive arc insofar as the 'racial' binds itself to the decision to pursue the future, the next generation." The claim in Cramblett articulates enduring beliefs about racial heritability and racial hierarchy within overarching regimes of value. It ultimately highlights that life's continuation is always-already racialized, and reproductive technologies, with the accompanying concept of biogenetic affinity, can fortify these operationsfurther conditioning the contours of racial futurity.

Open Access This article is licensed under a Creative Commons Attribution 4.0 International License, which permits use, sharing, adaptation, distribution and reproduction in any medium or format, as long as you give appropriate credit to the original author(s) and the source, provide a link to the Creative Commons licence, and indicate if changes were made. The images or other third party material in this article are included in the article's Creative Commons licence, unless indicated otherwise in a credit line to the material. If material is not included in the article's Creative Commons licence and your intended use is not permitted by statutory regulation or exceeds the permitted use, you will need to obtain permission directly from the copyright holder. To view a copy of this licence, visit http://creativecommons.org/licen ses/by/4.0/.

\section{References}

Adrian, S.W. 2020. Rethinking Reproductive Selection: Traveling Transnationally for Sperm. BioSocieties 15: 532-554.

Almeling, R. 2007. Selling Genes, Selling Gender: Egg Agencies, Sperm Banks and the Medical Market in Genetic Material. American Sociological Review 72 (3): 336-337.

Benjamin, R. 2018. Black Afterlives Matter: Cultivating Kinfulness as Reproductive Justice. Boston Review, 16 July, http://bostonreview.net/race/ruha-benjamin-black-afterlives-matter. Accessed 16 Oct 2020 
Bindel, J. 2014. Designer Babies? It Looks Like Racism and Eugenics to Me. The Guardian, 3 October, https://www.theguardian.com/commentisfree/2014/oct/03/sperm-donot-lawsuit-racism-eugenicslesbian-couple-black-donor. Accessed 16 Oct 2020.

Bliss, J. 2015. Hope Against Hope: Queer Negativity, Black Feminist Theorizing, and Reproduction Without Futurity. Mosaic: A Journal for the Interdisciplinary Study of Literature 48 (1): 83-98.

Brown, L.X.Z. 2018. Legal Ableism, Interrupted: Developing Tort Law and Policy Alternatives to Wrongful Birth and Wrongful Life Claims. Disability Studies Quarterly. https://doi.org/10.18061/ dsq.v38i2.6207.

Chandra, A., Copen, C. E., and Stephen, E. H. 2013. Infertility and impaired fecundity in the United States, 1982-2010: Data from the National Survey of Family Growth. National Health Statistics Reports, 67:1-19. https://www.cdc.gov/nchs/data/nhsr/nhsr067.pdf. Accessed 21 Aug 2020.

Cooper, M., and C. Waldby. 2014. Clinical Labor: Tissue Donors and Research Subjects in the Global Bioeconomy. Durham, NC: Duke University Press.

Cramblett v. Midwest Sperm Bank, LLC. Complaint for Wrongful Birth and Breach of Warranty. 29 Sept 2014. Circuit Court of Cooks County, Illinois.

Cramblett v. Midwest Sperm Bank, LLC. No. 15 L 000282. Motion to Dismiss Plaintiff's Complaint at Law.'2015. Circuit Court of Cooks County, Illinois.

Cuevas, M. 2014. Ohio Woman Sues Sperm Bank After Racial Mix-Up. CNN, 2 October, https://edition. cnn.com/2014/10/02/us/sperm-bank-race-lawsuit/index.html. Accessed 16 Oct 2020.

Daniels, C.R., and E. Heidt-Forsythe. 2012. Gendered Eugenics and the Problematic of Free Market Reproductive Technologies: Sperm and Egg Donation in the United States. Signs: Journal of Women in Culture and Society 12 (3): 719-747.

Davis, D. 2020. Reproducing While Black: The Crisis of Black Maternal Health, Obstetric Racism and Assisted Reproductive Technology. Reproductive BioMedicine and Society Online 11, https://www. rbmsociety.com/article/S2405-6618(20)30022-8/pdf. Accessed 20 May 2021.

Deomampo, D. 2016. Transnational Reproduction: Race, Kinship, and Commercial Surrogacy in India. New York: New York University Press.

Deomampo, D. 2019. Racialized Commodities: Race and Value in Human Egg Donation. Medical Anthropology 38 (7): 620-633.

Du Bois, W.E.B. 1999 [1920]. Darkwater: Voices from Within the Veil. Mineloa, NY: Dover.

Eng, D.L. 2010. The Feeling of Kinship: Queer Liberalism and the Racialization of Intimacy. Durham. Duke University Press.

Ehlers, N. 2012. Racial Imperatives: Discipline, Performativity, and Struggles Against Subjection. Bloominton: Indiana University Press.

Fanon, F. (2000 [1952]) The Fact of Blackness. In: Theories of Race and Racism: A Reader, ed. L. Back and J. Solomos, trans C.L. Markmann, 326-335. New York: Routledge.

Fielder, B. 2020. Relative Races: Genealogies of Interracial Kinship in Nineteenth-Century America. Durham: Duke University Press.

Foucault, M. 2003. Society Must Be Defended: Lectures at the Collège de France 1975-1976. New York: Picador.

Foucault, M. 2008. Birth of Biopolitics: Lectures at the Collège de France 1978-1979. New York: Picador.

Fox, D. 2021. Reproducing Race in an Era of Reckoning. Minnesota Law Review 105: 233-250.

Fox, D. 2014. Reproducing Race. Huffington Post, 6 October, https://www.huffpost.com/entry/reproducing-race_b_5942166. Accessed 1 Nov 2020.

Fox, D. 2009. Racial Classification in Assisted Reproduction. The Yale Law Journal 118 (8): 1844-1898.

Fullwiley, D. 2007. Race and Genetics: Attempts to Define the Relationship. BioSocieties 2 (2): 221-237.

Gilmore, R.W. 2015. The worrying state of the anti-prison movement. Social Justice Blog, February 23, http://www.socialjusticejournal.org/the-worrying-state-of-the-anti-prison-movement/. Accessed 1 Nov 2020.

Griffiths, D. 2016. The (Re)production of the Genetically Related Body in Law, Technology and Culture: Mitochondria Replacement Therapy. Health Care Analysis 24: 196-209.

Gutowski, C. 2015 Downers Grove Sperm Bank Seeks Dismissal of Case Involving Biracial Child. Chicago Tribune, 1 May, https://www.mcall.com/news/ct-dupage-lesbian-sperm-suit-folo-met-20150 501-story.html. Accessed 4 Nov 2020.

Harris, C. 2020. Reflections on Whiteness as Property. Harvard Law Review 134 (1): 1-10.

Harris, C. 1993. Whiteness as Property. Harvard Law Review 106 (8): 1707-1791. 
Harrison, L. 2016. Brown Bodies, White Babies: The Politics of Cross-Racial Surrogacy. New York: New York University Press.

Hartman, S. 2014. The Value of Whiteness: A Lawsuit is Being Waged Against the 'Wrongful Birth' of a Black Child. The Nation, 12 November, https://www.thenation.com/article/value-whiteness/. Accessed 4 Nov 2020.

Hartman, S. 1997. Scenes of Subjection: Terror, Slavery, and Self-making in Nineteenth-Century America. New York: Oxford University Press.

Holland, S.P. 2012. The Erotic Life of Racism. Durham: Duke University Press.

Houghton-Larsen, M.A. 2019. I Paid for a White Baby: How Assisted Reproductive Technologies Reproduce White Supremacy. Georgetown Journal of Law \& Modern Critical Race Perspectives 11 (2): $161-177$.

Johnson J. 2014. What's the Cost of 'Parenting While Black?: Sperm Bank Lawsuit May Have the Answer. Ebony, 3 October, https://www.ebony.com/life/white-lesbian-couple-sperm-bank-043/. Accessed 1 Oct 2020 .

Kahn J., A. Nelson, J.L. Graves Jr., et al. 2018. How Not To Talk About Race and Genetics. BuzzFeed. 30 March, https://www.buzzfeednews.com/article/bfopinion/race-genetics-david-reich. Accessed 9 Oct 2020.

Kearl, M.K. 2018. The Stolen Property of Whiteness: A Case Study in Critical Intersectional Rhetorics of Race and Disability. Rhetoric Review 37 (3): 300-313.

Kennedy, R. 2000. The Enforcement of Anti-miscegenation Laws. In Interracialism: Black-White Intermarriage in American History, Literature, and Law, ed. W. Sollors, 140-162. Oxford and New York: Oxford University Press.

Krupar, S., and N. Ehlers. 2017. Biofutures: Race and the Governance of Health. Environment and Planning D: Society and Space 35 (2): 222-240.

Lenon, S., and D. Peers. 2017. 'Wrongful' inheritance: Race, disability and sexuality in Cramblett v. Midwest Sperm Bank. Feminist Legal Studies 25: 141-163.

Lenhardt, R.A. 2017. The Color of Kinship. Iowa Law Review 102: 2071-2107.

Lipsitz, G. 1998. The Possessive Investment in Whiteness How White People Profit from Identity Politics. Philadelphia: Temple University Press.

López, I.H. 1996. White by Law: The Legal Construction of Race. New York: New York University Press. Livingston, G. and A. Brown. 2017 Intermarriage in the U.S. 50 Years After Loving v. Virginia. Pew Research Center, Social and Demographic Trends, 18 May. https://www.pewsocialtrends.org/2017/ 05/18/intermarriage-in-the-u-s-50-years-after-loving-v-virginia/. Accessed 1 Oct 2020.

Mamo, L. 2005. Biomedicalizing Kinship: Sperm Banks and the Creation of Affinity-Ties. Science as Culture 14 (3): 237-264.

Martin, L.J. 2017. 'They Don't Just Take a Random Egg': Egg Selection in the United States. In Selective Reproduction in the 21st Century, ed. A. Wahlberg and T. Gammeltoft, 151-170. Cham: Palgrave Macmillan.

McKnight, M. 2014 The Ohio Sperm-Bank Controversy: A New Case for Reparations? The New Yorker, Oct 14, https://www.newyorker.com/news/news-desk/ohio-sperm-bank-controversy-new-case-repar ations. Accessed 1 Oct 2020.

Melamed, J. 2015. Racial Capitalism. Critical Ethnic Studies 11 (1): 76-85.

Moll, T. Tessa. 2019. Making a Match: Curating Race in South African Gamete Donation. Medical Anthropology 38 (7):588-602.

Nelson, A. 2016. The Social Life of DNA: Race, Reparations, and Reconciliation After the Genome. Boston: Beacon Press.

Paul-Emile, K. 2018. When a Wrongful Birth Claim May Not Be Wrong: Race, Inequality, and the Cost of Blackness. Fordham Law Review 86: 2811-2820.

Petersen, N.M., and L. Myong. 2015. (Un)liveabilities: Homonationalism and Transnational Adoption. Sexualities 18 (3): 329-345.

Pollock, A. 2015. On the Suspended Sentences of the Scott Sisters: Mass Incarceration, Kidney Donation, and the Biopolitics of Race in the United States. Science, Technology, \& Human Values 40 (2): 250-271.

Quiroga, S.S. 2007. Blood is Thicker than Water: Policing Donor Insemination and the Reproduction of Whiteness. Hypatia 22 (2): 143-161.

Ryan, M., and A. Moras. 2017. Race Matters in Lesbian Donor Insemination: Whiteness and Heteronormativity as co-constituted Narratives. Ethnic and Racial Studies 40 (4): 579-596. 
Rich, C.G. 2020. Contracting Our Way to Inequality: Race, Reproductive Freedom and the Quest for the Perfect Child. Minnesota Law Review 104 (5): 2375-2469.

Robinson, C. 1983. Black Marxism: The Making of the Black Radical Tradition. Chapel Hill: University of North Carolina Press.

Roberts, D. 2011. Fatal Invention: How Science, Politics, and Big Business Re-create Race in the TwentyFirst Century. New York: The New Press.

Roberts, D. 1997. Killing the Black Body: Race, Reproduction, and the Meaning of Liberty. New York: Vintage Books.

Rose, N. 2007. Politics of Life Itself: Biomedicine, Power, and Subjectivity in the Twenty-First Century. Princeton: Princeton University Press.

Rose, N. 1996. Governing 'Advanced' Liberal Democracies. In Foucault and Political Reason, ed. A. Barry, T. Osborne, and N. Rose, 37-64. Chicago, IL: University of Chicago Press.

Russell, C.A. 2018. The Assisted Reproduction of Race. Indianapolis: Indiana University Press.

Saks, E. 2000. Representing Miscegenation Law. In Interracialism: Black-White Intermarriage in American History, Literature, and Law, ed. W. Sollors, 61-81. Oxford: Oxford University Press.

Singh, N.P. 2017. On race, Violence, and 'So-Called Primitive Accumulation.' In Futures of Black Radicalism, ed. G.T. Johnson and A. Lubin, 39-58. New York: Verso.

Shange, S. 2014. Black on purpose: Race, inheritance and queer reproduction. The Feminist Wire, October 10. http://thefeministwire.com/2014/10/black-purpose-race-inheritance-queer-reproduction/. Accessed 1 Oct 2020.

Spillers, H. 1987. Mama's Baby, Papa's Maybe: An American Grammar Book. Diacritics 17 (2): 65-81.

Stokes, M. 2001. The Color of Sex: Whiteness, Hetersexuality, and the Fictions of White Supremacy. Durham: Duke University Press.

Taylor, K. 2016. From \#BlackLivesMatter to Black Liberation. Chicago: Haymarket Books.

Thompson, C. 2005. Making Parents: The Ontological Choreography of Reproductive Technologies. Cambridge: MIT Press.

Valentine, D. 2020. The curious case of Cramblett v. Midwest Sperm Bank: Centering a political ontology of race and disability for liberatory thought. The Journal of Speculative Philosophy 34 (3): 424-440.

Waldby, C. 2019. The Oocyte Economy: The Changing Meaning of Human Eggs. Durham: Duke University Press.

Weinbaum, A.E. 2019. The Afterlife of Reproductive Slavery: Biocapitalism and Black Feminism's Philosophy of History. Durham: Duke University Press.

Vora, K. 2015. Life Support: Biocapital and the New History of Outsourced Labor. Minneapolis: University of Minnesota Press.

Yussof, K. 2019. A Billion Black Anthropocenes or None. Minneapolis: University of Minnesota Press.

Zack, N. 1993. Race and Mixed Race. Philadelphia: Temple University Press.

Publisher's Note Springer Nature remains neutral with regard to jurisdictional claims in published maps and institutional affiliations.

Nadine Ehlers teaches in the School of Social and Political Science at the University of Sydney, Australia. Ehlers' research broadly focuses on the socio-cultural study of the body, law, and biomedicine to examine the racial and gendered governance of individuals and populations. 